\title{
Novel Mutation in EIF2B Gene in a Case of Adult-Onset Leukoencephalopathy with Vanishing White Matter
}

\author{
Masaru Matsui $^{\mathrm{a}}$ Kotaro Mizutani ${ }^{\mathrm{d}} \quad$ Hiroaki Ohtake $^{\mathrm{e}}$ Yukio Miki $^{\mathrm{b}}$ Koichi Ishizu ${ }^{\mathrm{b}}$ \\ Hidenao Fukuyamac Takayoshi Shimohata ${ }^{\mathrm{e}}$ Osamu Onodera ${ }^{f}$ Masatoyo Nishizawa ${ }^{\mathrm{e}}$ \\ Yoshihiro Takayamag Hiroshi Shibasaki ${ }^{a, c}$
}

Departments of ${ }^{a}$ Neurology and ${ }^{b}$ Nuclear Medicine and Diagnostic Imaging and ${ }^{c}$ Human Brain Research Center, Kyoto University Graduate School of Medicine, Kyoto, ${ }^{d}$ Department of Neurology, Sakakibara Hakuho Hospital, Mie, Departments of ${ }^{\mathrm{e}}$ Neurology and ${ }^{\mathrm{f}}$ Molecular Neuroscience, Brain Research Institute, Niigata University, Niigata, and ${ }^{\text {gDepartment }}$ of Speech Physiology, Graduate School of Medicine, University of Tokyo, Tokyo, Japan

Dear Sir,

Leukoencephalopathy with vanishing white matter (VWM) [1], also referred to as childhood ataxia with diffuse central nervous system hypomyelination $(\mathrm{CACH})$ [2], is a newly described white matter disease characterized by autosomal recessive inheritance, chronic progressive cerebellar ataxia, spasticity and unique MRI findings. Recently, mutations in the 5 genes (EIF2B1 to EIF2B5) encoding the subunits of the eukaryotic translation initiation factor 2B (eIF2B), which plays an important role in the regulation of translation initiation of protein synthesis, have been identified as the cause of VWM $[3,4]$. We previously reported the first case of adult-onset VWM of Asian origin based on clinical diagnostic criteria [5]. Herein, we report the findings of a genetic study of this case that identified a novel EIF2B mutation.

Our female patient developed slowly progressive gait disturbance and hand clumsiness at the age of 42 [5]. Neurological findings included cerebellar ataxia, exaggerated deep tendon reflexes with bilateral Babinski sign and mild mental decline. Cranial MRI showed that the cerebral white matter was symmetrically and diffusely abnormal with a signal intensity close to that of the cerebrospinal fluid in some parts. All of these results were consistent with a clinical diagnosis of VWM $[1,4]$. In addition, the disease progression was very slow, and her clinical state remained nearly stable for several years.

A genetic analysis was performed, using a method previously described [6]. In brief, DNA was extracted from a blood sample after obtaining informed consent from the patient. The entire coding regions of EIF2B2 and EIF2B5, which encode $\mathrm{eIF} 2 \mathrm{~B} \beta$ and $\mathrm{eIF} 2 \mathrm{~B} \varepsilon$, respectively, were amplified using the PCR primer sets listed at http://www.vumc.nl/whitematter. After purification of the PCR products, direct sequencing was performed using an ABI PRISM 3100 Genetic Analyzer (Applied Biosystems, Foster City, Calif., USA). The result revealed a novel G1459A missense mutation in the EIF2B5 gene (fig. 1A). This mutation in EIF2B5 leads to a substitution of glutamic acid for lysine in $\mathrm{IIF} 2 \mathrm{~B} \varepsilon$ at position 487 (E487K). Forty-four unrelated Japanese control subjects did not show this mutation (fig. 1B).

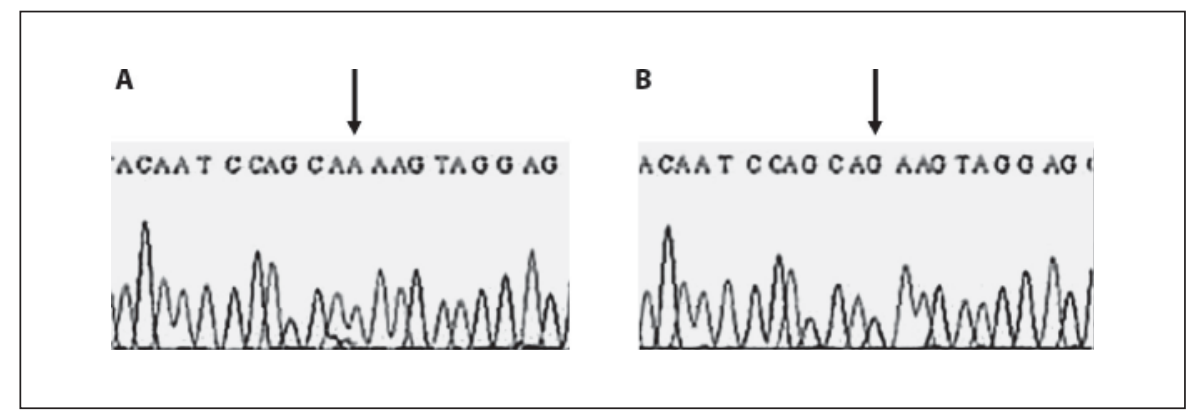

Fig. 1. Sequencing electropherogram images showing the G1459A transition in EIF2B5 in the patient ( $\mathbf{A}$, arrow) compared with a control subject (B, arrow).

\section{KARGER}

Fax +41613061234 E-Mail karger@karger.ch www.karger.com www.karger.com/ene
Dr. Masaru Matsui

Department of Neurology, Kanazawa Medical University

1-1 Daigaku, Uchinada, Kahoku-gun

Ishikawa 920-0293 (Japan)

Tel. +81 76286 2211, Fax +81 76286 3259, E-Mail masarum@kanazawa-med.ac.jp 
There are 77 different mutations in EIF2B that have been described thus far in $148 \mathrm{VWM} / \mathrm{CACH}$ patients, most of which are missense mutations [7]. In adult-onset cases, R113H [8] and T182M [6] in eIF2B $\varepsilon$ have been reported. No apparent correlation has been found between the affected subunits and disease severity, though correlations between certain mutations at the homozygous state and the age of disease onset and severity have been reported [7]. Further, VWM/CACH patients with the homozygous mutation, $\mathrm{R} 113 \mathrm{H}$ in $\mathrm{eIF} 2 \mathrm{~B} \varepsilon$ $[8,9]$ and E213G in eIF2B $\beta$ [9] have been shown to express milder forms of the disease. In our patient, the age at disease onset was relatively advanced, and the clinical course has been apparently mild to date. It remains to be determined whether the novel EIF2B mutation identified in this case is associated with a milder form of $\mathrm{VWM} / \mathrm{CACH}$.

\section{Acknowledgment}

The authors thank Dr. Ryosuke Takahashi for helpful comments.

\section{References}

1 Van der Knaap MS, Barth PG, Gabreëls FJ, Franzoni E, Begeer JH, Stroink H, Rotteveel JJ, Valk J: A new leukoencephalopathy with vanishing white matter. Neurology 1997;48: 845-855.

2 Schiffmann R, Moller JR, Trapp BD, Shih HH, Farrer RG, Katz DA, Alger JR, Parker CC, Hauer PE, Kaneski CR, Heiss JD, Kaye EM, Quarles RH, Brady RO, Barton NW: Childhood ataxia with diffuse central nervous system hypomyelination. Ann Neurol 1994;35:331-340.

3 Leegwater PA, Vermeulen G, Könst AA, Naidu S, Mulders J, Visser A, Kersbergen P, Mobach D, Fonds D, van Berkel CG, Lemmers RJ, Frants RR, Oudejans CB, Schutgens RB, Pronk JC, van der Knaap MS: Subunits of the translation initiation factor eIF2B are mutant in leukoencephalopathy with vanishing white matter. Nat Genet 2001;29:383388.

4 Van der Knaap MS, Leegwater PA, Könst AA, Visser A, Naidu S, Oudejans CB, Schutgens RB, Pronk JC: Mutations in each of the five subunits of translation initiation factor eIF2B can cause leukoencephalopathy with vanishing white matter. Ann Neurol 2002; 51:264-270.
5 Matsui M, Mizutani K, Miki Y, Mezaki T, Takahashi Y, Shibasaki H: Adult-onset leukoencephalopathy with vanishing white matter. Eur J Radiol Extra 2003;46:90-92. DOI:10.1016/S1571-4675(03)00054-3.

6 Ohtake H, Shimohata T, Terajima K, Kimura T, Jo R, Kaseda R, Iizuka O, Takano M, Akaiwa $Y$, Goto $\mathrm{H}$, Kobayashi $\mathrm{H}$, Sugai $\mathrm{T}, \mathrm{Mu}-$ ratake T, Hosoki T, Shioiri T, Okamoto $\mathrm{K}$, Onodera O, Tanaka K, Someya T, Nakada T, Tsuji S: Adult-onset leukoencephalopathy with vanishing white matter with a missense mutation in EIF2B5. Neurology 2004;62: 1601-1603.

7 Fogli A, Boespflug-Tanguy O: The large spectrum of eIF2B-related diseases. Biochem Soc Trans 2006;34:22-29.

8 Van der Knaap MS, Leegwater PA, van Berkel CG, Brenner C, Storey E, Di Rocco M, Salvi F, Pronk JC: Arg113His mutation in eIF2B $\varepsilon$ as cause of leukoencephalopathy in adults. Neurology 2004;62:1598-1600.

9 Fogli A, Schiffmann R, Bertini E, Ughetto S, Combes P, Eymard-Pierre E, Kaneski CR, Pineda M, Troncoso M, Uziel G, Surtees R, Pugin D, Chaunu MP, Rodriguez D, Boespflug-Tanguy $\mathrm{O}$ : The effect of genotype on the natural history of eIF2B-related leukodystrophies. Neurology 2004;62:1509-1517. 